\title{
Research on the Influence of University-Enterprise Cooperation on the Employment of Engineering Talents in Financial Institutions
}

\author{
Guangyu $\mathrm{Mu}$ \\ School of Management Science and Information \\ Engineering \\ Jilin University of Finance and Economics \\ Changchun130117, China \\ guangyumu@126.com \\ Mengdi Ge \\ School of Applied Mathematics \\ Jilin University of Finance and Economics \\ Changchun130117, China \\ 1454694623@qq.com
}

\author{
Qing $\mathrm{Xu}$ \\ School of Management Science and Information \\ Engineering \\ Jilin University of Finance and Economics \\ Changchun130117, China \\ 1162731344@qq.com
}

Xiuli $\mathrm{Si}^{*}$

College of Information Technology

Jilin Agricultural University

Changchun130118, China

157935353@qq.com

\begin{abstract}
University-enterprise cooperation is an important measure to deepen the reform of higher education system and an innovative mode to cultivate talents. This paper aims to explore the aspects in which university-enterprise cooperation affects the employment of engineering undergraduates. Through the empirical analysis method, we analyze the compound characteristics of engineering talents training in the financial institution and put forward the working mode of collaborative education in the college of management science and information engineering of Jilin University of Finance and Economics based on the Mycos employment real data. Then we creatively construct an evaluation index system, including the employment rate, employment and specialty relevance, enterprises' satisfaction with undergraduates and undergraduates' satisfaction with jobs. Finally, we demonstrate the influence of university-enterprise cooperation on undergraduate employment competitiveness. The results show that university-enterprise cooperation has an incentive effect on the employment of the engineering talents in financial institutions.
\end{abstract}

Keywords-University-enterprise cooperation; Employment; Impact assessment; Financial institution; Engineering talent

\section{INTRODUCTION}

The origin of university-enterprise cooperation can be traced back to the 19th century and the prototype was Germany's dual system. At present, the definition of universityenterprise cooperation is a new talent training mode [1] that aims to meet employment demands in China. According to the needs of the society and enterprises, universities and enterprises jointly participate in the training of talents using employment as a compass. In order to cultivate better talents,

The research was supported by the National Social Science Foundation of China under grant No. 15BGL090, the National education science planning ministry of education key project under Grant No. DIA 170365 and Jilin province higher education teaching reform project "Based on the "one body, two wings, three belts' mode of financial university engineering talent innovation and entrepreneurship education evaluation system practice research". universities need equipment and scientific research funds, Moreover, enterprises need high-quality applied talents and scientific research achievements forcing in the peers. Hence, the complementary demand of both sides is the basis of promoting the cooperation between university and enterprise. University-enterprise cooperation provides a valuable platform for the employment of undergraduates. Meanwhile, it sets a solid foundation for the improvement of the quality of talents and integrates society, enterprise and higher education into a whole [2]. In short, university-enterprise cooperation has an impact on students, university and enterprise, especially on employment of undergraduate, which is the theme of our research.

\section{Characteristics OF ENGiNEERING TALENTS TRAINING IN FINANCIAL INSTITUTION}

Financial institutions have a dense financial atmosphere. Furthermore, economic and management are the advantages of the development of disciplines. This characteristic provides a composite development mode for training engineering talents. Taking the School of Management Science and Information Engineering of Jilin University of Finance and Economics for example, there are three undergraduate majors in the college including computer science, information technology and electronic commerce. Our college is committed to cultivating high-quality composite applied talents [3] with strong creative spirit and practical ability in order to meet the needs of social and economic development easily.

The university-enterprise cooperation mode is beneficial to cultivate compound talents. As a result, the training direction of engineering talents in colleges and universities of finance and economics is more diversified. The effect of universityenterprise cooperation on the employment of talents in the 
financial institution is different from those in universities of science technology and comprehensive universities. On the whole, the focus of this paper is how to evaluate the influence on undergraduates under this cooperation mode.

\section{UNIVERSITY-ENTERPRISE COOPERATION IN SCHOOL OF MANAGEMENT SCIENCE AND INFORMATION ENGINEERING FROM JILIN UNIVERSITY OF FINANCE AND ECONOMICS}

In order to improve the quality of personnel training and achieve seamless connection with the actual needs of society, the college has established a cooperative education model of "co-cultivation, orientation education, joint assessment, twoway selection and enterprise use". This model thinks highly of students' practice, university-enterprise interaction and workstudy integration. In addition, university-enterprise cooperation improves students' practical training skills and expands internship and employment. The university-enterprise cooperation model is showed in Fig. 1.

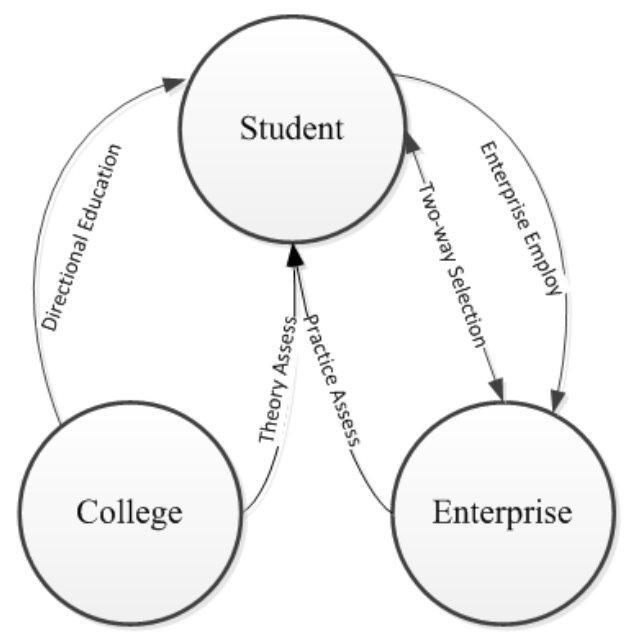

Fig. 1. University-enterprise cooperation model

Taking the social needs as the entry point, the college establishes practical teaching bases for the government, university, and enterprise. The college also effectively conducts the practical training. For instance, the college organizes systematic cognition internships, winter camps, summer camps and other teaching and internship activities. Another case in point is that the college carries out university-enterprise cooperation to create a deep-integration education system. Besides, the college implements innovative dual-teacher development models, which can broaden student's knowledge and enrich their technology. Our college attaches great attention to the theory teaching, laboratory comprehensive training and enterprise application practice. Meanwhile, our talent training program embodies the combination of theory learning, engineering training and enterprise practice. In addition, this program equally emphasizes on theory and practice, and combines production, learning, and research closely.
IV. The ENERGETIC INFLUENCE OF UNIVERSITYENTERPRISE COOPERATION ON THE EMPLOYMENT OF IT TALENTS IN FINANCIAL INSTITUTIONS

\section{A. Cooperative Enterprises Provide Direct Employment Exports}

Our college builds the university-enterprise cooperative education mode which is called "integration of internship and employment" to achieve order-based training. The college has established an off-campus training base with 19 well-known enterprises, including Asia Info Technology (China), Neusoft Group, and Hua Xin Yong Dao Corporation, etc. The enterprises have a wide geographical coverage and directly provide employment for undergraduates of our college. Relying on the powerful resources of university-enterprise cooperation, our college holds many special cooperative companies recruitment meetings each year. In recent five years, cooperative enterprises have employed more than 230 students from our college.

The workflow of internship and employment is shown in Fig. 2

\section{B. University-Enterprise cooperation strengthens the Employment Competitiveness of Undergraduates}

There are a large number of evaluation indicators for undergraduates' employment competitiveness, such as professional thinking, professional practice ability, professional adaptability and career development potential [5]. These evaluation indicators pay attention to considering undergraduates' ability and quality. It is difficult to quantify and unify these evaluation indicators. Because the employment competitiveness of undergraduates is directly reflected in the quality of employment, we use the quality of employment to reflect the strength of employment competitiveness in this article. Considering the influence of university-enterprise cooperation on employment, this paper uses employment rate, employment and specialty relevance, enterprises' satisfaction with undergraduates, and undergraduates' satisfaction with the jobs to evaluate the quality of undergraduate employment [6].The data of university-enterprise cooperation in this article come from Mycos quality evaluation data of 2016 undergraduates in Jilin University of Finance and Economics and our college's survey tracking data which is true and effective.

\section{1) The Employment Rate}

For five years, the college was awarded the honorary titles of advanced collective employment at the university and provincial level. The employment rate of the undergraduates is the best among the 39 undergraduate majors in our university. Taking the employment rate of the 2016 college undergraduates as an example, by August 31st, the employment rate of management science and information engineering college undergraduate ranks the first in the whole university, reaching 94\%. The employment rate is shown in Fig. 3. 


\section{2) The Employment and Specialty Relevance}

Because of the compound characteristics in the college talents training, the students have greater freedom in the fields of employment.

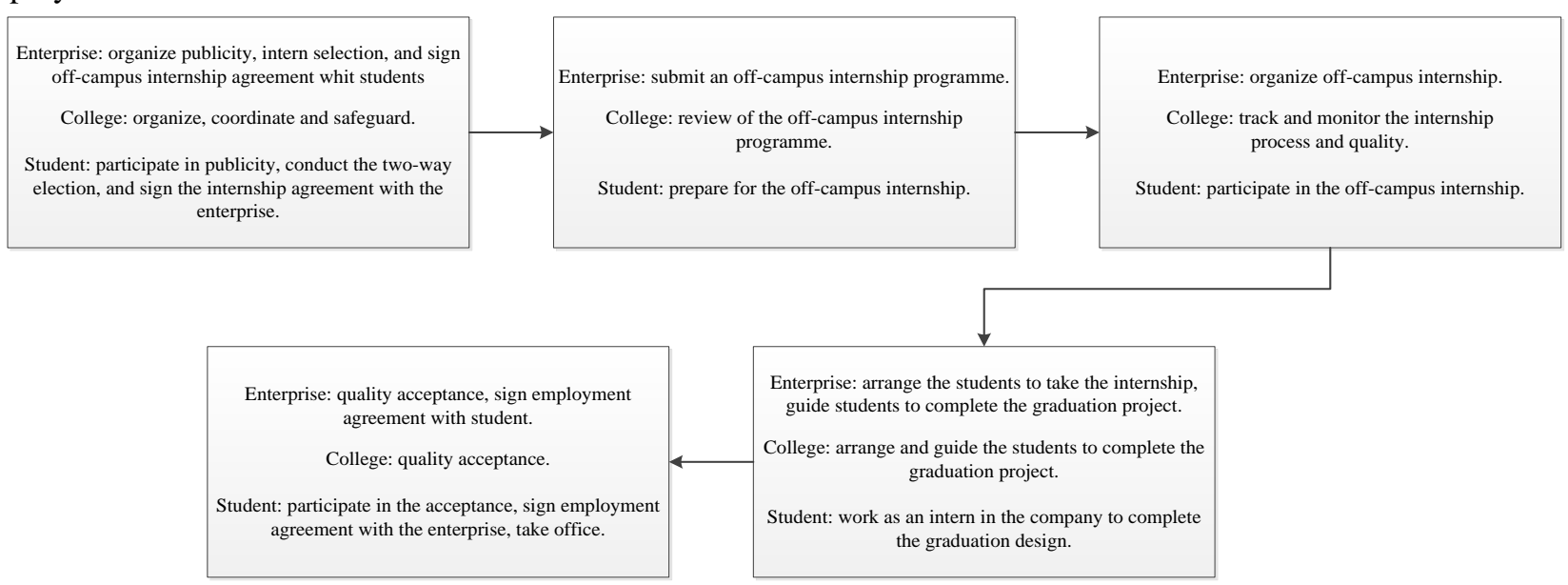

Fig. 2. Off-campus internship workflow

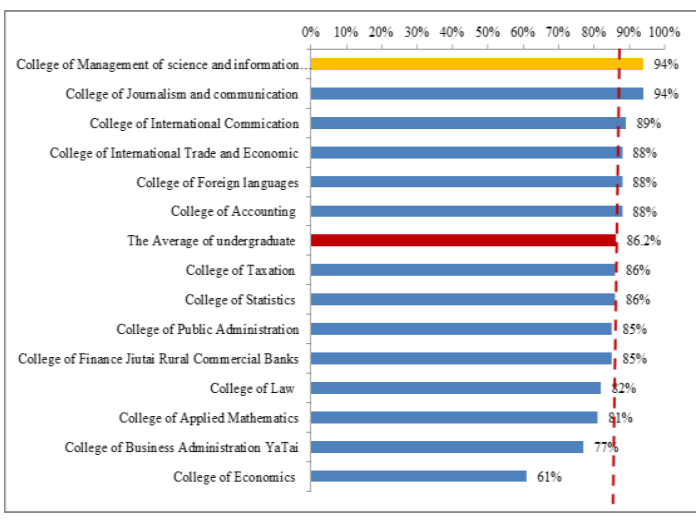

Fig. 3. Employment rate

Students work in financial institutions, government agencies, enterprises, and so on. Most of their positions are information processing, computer applications, systems analysis, design and development and e-commerce. In 2016, the relevance of employment and specialty reached $87 \%$ (such as Fig. 4) in our college.

\section{3) Enterprises' Satisfaction with Undergraduates}

Employers evaluate undergraduates in 13 aspects including responsibility, innovative ability, interpersonal skills, team spirit, professionalism, compressive ability, logic analysis ability, hard-working spirit, practical ability, courage, management ability, dedication and vision [7]. The evaluation results consisted of four grades, which are quite satisfaction, satisfaction, basic satisfaction and dissatisfaction. Fig. 5 is the enterprises' satisfaction with undergraduates of our college.

$57 \%$ of the enterprises were quite satisfied, $30 \%$ were satisfied and $9 \%$ were basically satisfied. The feedback results showed that the employers were highly satisfied with the undergraduates. In addition, the college extensively investigates the comprehensive quality and other aspects of

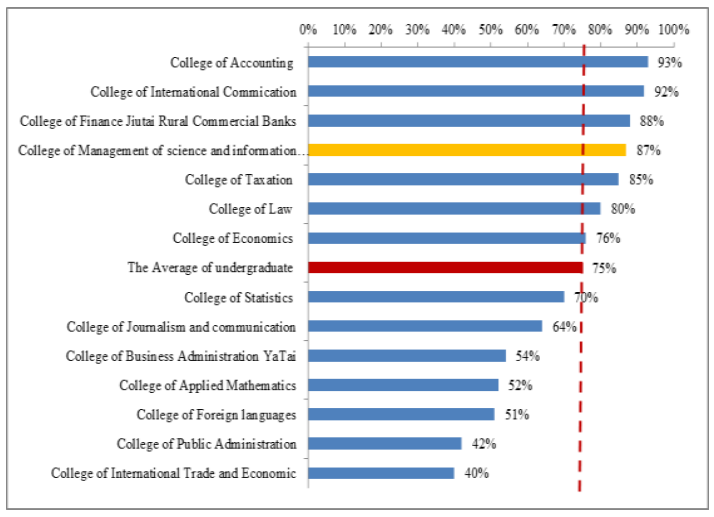

Fig. 4. Employment and specialty relevance

undergraduates every year. The feedback results indicate that our undergraduates hold solid foundation, strong program development and design ability, team cooperation spirit and other characteristics. As a result, they are well recognized by employers.

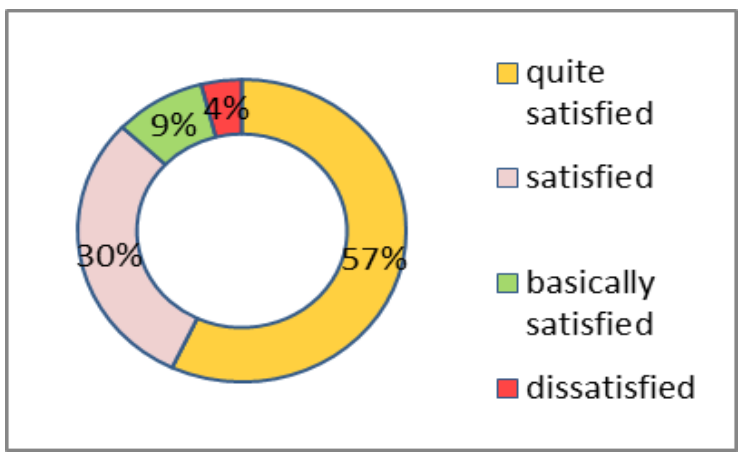

Fig. 5. Enterprises' satisfaction with undergraduates 


\section{4) Undergraduates' Satisfaction with jobs}

Comparing with 13 other colleges on campus horizontally, our undergraduates' satisfaction with jobs is ranked fifth in the university with $74 \%$ satisfaction in the survey of 2016 undergraduates. This data is above the average level. The Fig. 6 shows the undergraduates of our college have a relatively high degree of satisfaction with jobs.

The university-enterprise cooperation not only broadens the internship training channels but also improves the practiced ability. Thus, the employment rate is effectively promoted [8]. Meanwhile, university-enterprise cooperation makes incentive effect on employment of the personnel who major in engineering specialties in financial institutions. The cooperation mode is well received by enterprises, universities and students.

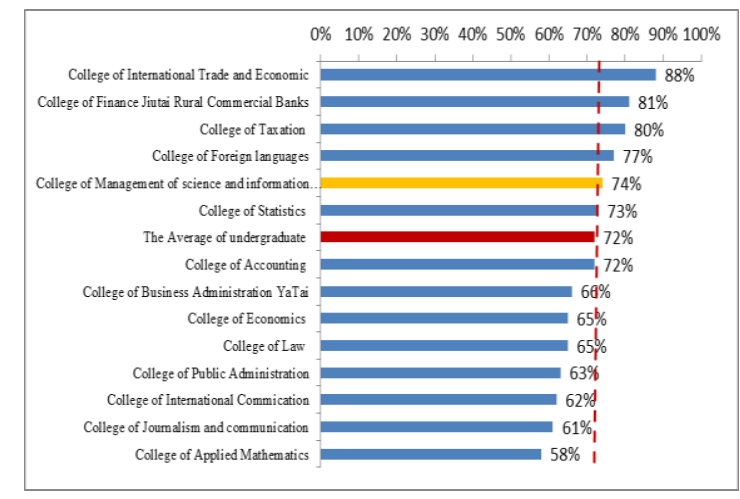

Fig. 6. Undergraduates's satis faction with jobs

\section{The Positive Feedback Regulation Mechanism of UNIVERSITY-ENTERPRISE COOPERATION}

The working effect of a system regulates the system itself again, which is called feedback regulation in biology. By analogy with the biological system, the three main bodies of student, university and enterprise are defined as a system. The working effect of university-enterprise cooperation has an influence on the three bodies of the system. Then, the influence is an input variable to adjust the whole system. It has been proved by practice that this kind of positive feedback regulation mechanism enables the student, university, and enterprise to form a virtuous circle of cooperation.

Therefore, it is indispensable to strengthen universityenterprise cooperation basis and innovate university-enterprise cooperation mode and talent cultivation pattern. And it is necessary to accelerate the innovation of university-enterprise cooperation system mechanism and deepen cooperation between university and enterprise. In the future, we hope that university-enterprise cooperation will achieve a win-win-win situation, namely, complementary advantages, resource sharing and improvement of the students' employment competitiveness.

\section{SUMMARY}

The working mode of cooperative education in our college is based on the construction of university-enterprise cooperation platform, and actively explores the innovative mode of talent cultivation [10]. We adhere to the principle of "do not be independent of industry ", enhance the quality of personnel training, and play a significant role in improving the employment environment of undergraduates.

\section{ACKNOWLEDGMENT}

The research was supported by the National Social Science Foundation of China under grant No. 15BGL090, the National education science planning ministry of education key project under the intelligent learning environment" under Grant No. DIA170365 and Jilin province higher education teaching reform project 'Based on the 'one body, two wings, three belts' mode of financial university engineering talent innovation and entrepreneurship education evaluation system practice research".

\section{REFERENCES}

[1] Juan Xing, “The study on university-enterprise cooperation to improve the employment competitiveness of the full-time master students of engineering," China University of Petroleum, 2015. (In Chinese)

[2] Siqun Gan, "Research on the mode of university-enterprise cooperation based on the combination of engineering and science," Industrial \& Science Tribune, vol. 16(22), pp. 247-248, 2017. (In Chinese)

[3] Yuli Chi, "Reform and practice of the training mode of e-commerce talents in higher vocational education," E-Business Journal, vol. 8, pp. 83-84, 2015. (In Chinese)

[4] Sanmei Ye, and Jianbing Chen, "The Integration of Production and Education: A Study of School-Enterprise Cooperation Model. Application-oriented Universities," Journal of Baise University, vol. 30(2), pp. 132-135, 2017. (In Chinese)

[5] Yan Li, Qiaoling Qi, and Jun Zhang, "Construction of Employment Competency Model for Computer Science and Technology Specialty,' Education and Teaching Forum, vol. 27, pp. 39-40, 2017. (In Chinese)

[6] Zhimin Liu, and Bing $\mathrm{Wu}$, "Research on the influence factors of enterprises participating in the training of college enterprise cooperative talents in Vocational school," Higher Engineering Education Research, vol. 2, pp. 143-147, 2016. (In Chinese)

[7] Xin Guo, "Research on the training of Chinese Contemporary College Students'employability," Jilin University, 2017. (In Chinese)

[8] Jizhi Chen, "Analysis on influencing factors and related countermeasures of graduates' employability in higher vocational colleges," Yunnan University, 2013. (In Chinese)

[9] Guixiang Chen, "Analysis on the formation of innovative entrepreneurial talent cultivation mechanism with linkage coupling between universities, government and enterprises -- based on the threehelix theoretical perspective," University Education Science, vol. 149, pp. 42-47, 2015. (In Chinese)

[10] Zhaonan Mu, "Effective Way and Method of Education through University-Enterprise Cooperation Based on University-Enterprise Benefit Community," 3rd International Conference on Education, Management, Arts, Economics and Social Science, pp. 152-156, 2015. 